\title{
SCIENTIFIC AND TECHNICAL RESEARCH IN ARGENTINA
}

$\mathrm{T}$ HE annual report (February 1, 1961-January 31,1962 ) of the National Council for Scientific and Technical Research of the Argentine Republic has recently been published.

One of the main activities of the Council continues to be the award of fellowships, with the object of training for research. In the period covered by the report, 146 fellowships were granted, 53 of them to carry out research projects in scientific institutions abroad and 93 for the same purpose in Argentina, apart from numerous extensions of fellowships granted the previous year. The total amount of fellowships awarded by the Council during the four years of its existence is 571, of which 319 were awarded for research carried out in Argentina and 252 abroad. Reports received from universities and research centres of the United States, Great Britain, France and other countries which have received Council Fellows emphasize the high standard and achievements of these men.

During the period covered by the report, the Council has intensified its aid to different research projects by means of grants. The total amount granted exceeded 80 million Argentine pesos.

Grants are awarded primarily for the purchase of scientific equipment and to finance research projects. In some cases they have been awarded for the building of new laboratories, for example, the Institute of Computing, Faculty of Exact and Natural Sciences, University of Buenos Aires; the Radiocarbon Dating Laboratory for Archæological and Geological Research, being installed at La Plata University as a joint project of the Council and the former; the Laboratory of Neurophysiology, already operating in the Institute of Experimental Biology and Medicine, located in Buenos Aires. The Council has also contributed towards equipping and staffing the Town Planning Institute of the Universidad del Litoral, in Rosario. In all such cases and other similar ones, the Council, while awarding the funds for the creation of new research centres, resolved that they should operate under the ægis of other institutions.

Lately, however, the Council has decided to create some research centres under its own jurisdiction. This is considered a fitting way to establish new research facilities for Argentine scientists, and will permit a better co-ordination of efforts in certain fields, apart from filling some scientific gaps. The aim is to organize a few model institutes, and to this end numerous projects are actually under investigation by the Council.

In another section of the report it is mentioned that during 1961 the 'Research Scientist's Career' was put into operation. This programme has been established by the Council with the objeet of fostering full-time dedication to original research, offering investigators better conditions than heretofore from the point of view of financial security and advancement, while tending to making research an attractive proposition for young graduates with a scientific vocation. Registration was opened by mid-1960, and applications filed up to the end of March 1962 totalled 494 of which 276 applicants were admitted. Of these, about 200 scientists have already complied with the necessary formalities and are actively engaged in research work within the scheme. Applications continue to be filed in considerable numbers, revealing a healthy interest in scientific research among young university graduates.

The Council has continued with its programme of inducing qualified Argentine research scientists settled abroad to return to the country. The report points out that it has been possible to retrieve Argentine men of science who held important positions in well-known foreign institutions by using funds earmarked for repatriation purposes. Increasingly favourable conditions for scientific research which have been ereated in the country during the past few years have, of course, played a predominant part.

During 1961, the Council considerably stepped up the programme aiming at the improvement of teaching scientific subjects at high-school level. With this object in mind, the Council has made available to secondary school science teachers the opportunity of improving their knowledge by attending refresher courses in the country and also abroad. A physics summer course for secondary school teachers, selected from all over the country, was held at the beginning of 1961. Four more courses were organized for the summer of 1962 , in mathematics, physics, chemistry and biology. A total of 123 high-school teachers attended these courses.

During 1961, two Argentine high-school teachers (mathematics and physics) attended the Oak Ridge Institute of Nuclear Studies, in Tennessee, while six others attended summer school courses organized by the U.S. National Science Foundation. It has also been possible to send some Argentine high-school teachers to refresher courses organized by the PanAmerican Union in other Latin-American countries.

Simultaneously, efforts are being made by the Council to bring up to date science teaching at secondary school level in Argentina and also to foster the interest of high-school graduates in seientific careers.

Mention is made of the different services rendered to research scientists by the Council, such as making available scientific information by means of microfilm, photostats, publications, etc.

Another chapter of the report refers to international scientific relations and contacts established by the Council. It is stated that the Council is the national member of the International Council of Scientific Unions (ICSU), the International Council for Medical Sciences (CIOMS), the International Committee on Space Research (COSPAR) and the International Federation of Documentation (FID).

Another aspect of contacts with scientific circles abroad are the invitations extended by the Council to foreign scientists of international standing in order to lecture in Argentina or to act in an advisory capacity on research projects. Argentine delegates are also sent by the Council to many international scientific meetings. It is pointed out that the Council finances the attendance of Argentine scientists at international meetings when certain conditions are fulfilled by the candidates, such as authorship of a paper on original research work which has gained 
acceptance by the organizing committee of the meeting. Due emphasis is given to the generous aid received from the Ford and Rockefeller Foundations of the United States which has enabled the Council to extend considerably its fellowship programme and has helped to finance some of the activities already mentioned.

A brief analysis of the Council's budget for the fiscal year which ended on October 31, 1961, shows that the amount budgeted was Argentine pesos $211,386,009,90$ (about $£ 1$ million at the then prevailing rate of exchange). Expenditures for the same period did not amount to the total budgeted, and it is note. worthy that administrative expenses amounted to only 8 per cent of the total expenditure.

During 1961, the Council resolved to buy a building in order to have more adequate premises. The future address is Rivadavia 1917, Buenos Aires, Argentina, where the Council expects to move before the end of the year, once the necessary alterations have been completed.

In the final part of the report, overall aspects of the Council's task are given consideration. They can be summed up by the considerable increase of young scientists adequately trained for research; the larger volume of research work undertaken in Argentina with the aid of Council funds granted to institutions and scientists; the establishing of new research teams and research contres and the higher level attained by research work in different fields. It is emphasized that the activity of the Council, combined with that of some other institutions carried out along similar lines in the past few years, has established a most favourable environment for original and creativo scientific research by fostering the general interest in scientific activity and obtaining increased aid for its continuation from official quarters as well as from the general public.

\section{CYTOCHEMICAL PROGRESS IN ELECTRON MICROSCOPY}

$\mathrm{T}$ HE symposium on "Cytochemical Progress in Electron Microscopy", which was held by the Royal Microscopical Society in Oxford during July 2-4, was a success both in the size of the attendance and the interest of the topics. The majority of those attending were British, but several papers were submitted from France and others from Belgium, the United States, Holland and Sweden.

The information presented fell into four categories. (1) Effects of different fixatives, embedding media and electron-absorbing 'stains' on morphological detail. (2) Sub-microscopic localization of enzymes utilizing electron-absorbing cytochemical reaction products. (3) The effects on morphological detail of extraction by chemical or onzymatic reagents. (4) Autoradiography at electron-microscope magnifications. It is a pity that the symposium was not organized to present consecutively the papers covered by these or similar headings. As it was, the fragmentation of discussion of any one topic prevented the important points resulting from it from being clearly presented to the non-specialist in the audience.

Under the first of the headings which I have chosen here, Dr. W. Bernhard and Dr. Elizabeth Leduc (Villejuif, France) presented beautiful pictures of the striking difference in appearance produced in tissues embedded in water-soluble glycol-methacrylate, compared with those embedded in media soluble only in organic solvents. 'These results were enlarged on by Dr. V. Marinozzi (Villejuif), who presented much useful information on differences produced by fixation in various solutions and embedding in different non-water-soluble media. Much technical information will be available as a result of the investigations of Dr. J. Sikorski (Leeds) on keratinous cells, of Dr. J. R. Casely-Smith (Villejuif) on fixation and staining of lipids, and of Dr. E. H. Mercer (London) and Drs. W. Th. Daems and J. P. Persijn (Leydon, Holland) on 'stains' for electron microscopy. The papers of Drs. E. L. Benedetti and B. Bertolini (Amsterdam), on the use of phosphotungstic acid as a stain for the plasma membrane, and Dr. R. L. Tapp (Cambridge), on the fine structure of desmosomes after a variety of techniques, illustrated the necessity of studying cell structure after using a variety of methods of preparation before attempting to interpret the functional significance of the details detected.

The value of using light-microscopy to investigate material and the changes which occur in it during preparation for electron microscopy was underlined by the papers of Prof. N. A. Barnicott (London) and Dr. H. E. Huxley (Cambridge) on their investigations of chromosomes and Dr. H. G. Davies (London) on his experiments with erythrocyte nuclei. It is to be hoped that the structureloss nature of the chromosomes which was so beautifully displayed may be due to fixation artofacts as was suggested by the information provided by Dr. B. M. Richards (London) in the discussion.

The most striking results in cytochemical investigations at the electron-microscope level have been those of the American and German workers using enzyme reaction products containing heavy metals. In the absence of these original contributors Dr. A. ( ${ }_{x}$. E. Pearso (London) gave a lucid account of the possibilities of this approach. He pointed out the incompatibility of good osmium fixation and the preservation of some enzymes, but also indicated that a method giving a bad picture at the light-microscope level might give a good one in the electron microscope. $\mathrm{He}$ also warned that much shorter incubation of tissues in substrates would probably be required if good electron micrographs devoid of diffusion of reaction product were to be obtained. Drs. S. J. Holt and Marian Hicks (London) illustrated many of these points with their paper on the localization of acid phosphatase in lysosome-like particles. Drs. G. de Thé, A. B. Novikoff and J. W. Beard (North Carolina) showed among other things that virus particles on entering and leaving a cell not only acquired a covering of part of the cellular membranes but also the adenosine triphosphatase activity associated with these membranes. It is this sort of result which makes the detailed work of eytochemistry at the electron-microscope level worth while. Dr. B. Boothroyd (Liverpool), in his paper on the effect of electron irradiation on glycogen, showed pictures of this polysaccharide stained by the periodic acidSchiff technique, which illustrates that deposition 